\title{
22. DINOFLAGELLATE BIOSTRATIGRAPHY OF NEOGENE AND QUATERNARY SEDIMENTS AT HOLES 400/400A IN THE BAY OF BISCAY (DEEP SEA DRILLING PROJECT LEG 48)
}

\author{
Rex Harland, Institute of Geological Sciences, Ring Road Halton, Leeds, LS15 8TQ, United Kingdom
}

\begin{abstract}
A tentative fourfold dinoflagellate cyst zonation is erected for middle Miocene to Recent sediments in the Bay of Biscay. In addition, an account of the Pliocene to Recent environments of the area is presented, and linked, where possible, to changes in the North Atlantic oceanic circulation and to changes in climate. Certain dinoflagellate cyst assemblages, similar to Recent cyst assemblages, are recognized from the Pleistocene sediments of the area, and are used in the environmental interpretation. A systematics section includes descriptions of the new species Amiculosphaera umbracula gen. et sp. nov.; Operculodinium crassum sp. nov.; Spiniferites splendidus $\mathrm{sp}$. nov.; and ?Pyxidiella simplex sp. nov.
\end{abstract}

\section{INTRODUCTION}

Leg 48 of the Deep Sea Drilling Project drilled eight holes in the eastern North Atlantic: four in the Bay of Biscay and four in the Rockall area. This account together with the results presented in the site reports (Chapter 3 , this volume) describes the dinoflagellate cysts recovered from the Cenozoic sediments cored at the Biscay sites. Costa and Downie (this volume) give the results of dinoflagellate cyst analyses of Cenozoic sediments from the Rockall Plateau.

The Bay of Biscay sites are situated some $322 \mathrm{~km} \mathrm{(200}$ miles) west of Brest (Brittany) and were drilled to investigate the structural and stratigraphic evolution of a passive ocean margin. They are as follows:

Site 399 , lat. $47^{\circ} 23.40^{\prime} \mathrm{N}$; long. $09^{\circ} 13.30^{\prime} \mathrm{W}$, in $4399 \mathrm{~m}$ of water

Holes $400 / 400 \mathrm{~A}$, lat. $47^{\circ} 22.90^{\prime} \mathrm{N}$; long. $09^{\circ} 11.90^{\prime} \mathrm{W}$, in $4399 \mathrm{~m}$ of water

Site 401 , lat. $47^{\circ} 25.65^{\prime} \mathrm{N}$; long. $08^{\circ} 48.62^{\prime} \mathrm{W}$, in $2495 \mathrm{~m}$ of water

Holes $402 / 402 \mathrm{~A}$, lat. $47^{\circ} 52.48^{\prime} \mathrm{N}$; long. $08^{\circ} 50.44^{\prime} \mathrm{W}$, in $2339.5 \mathrm{~m}$ of water

A list of the examined samples is provided in the Appendix to this report. All of the samples were processed using normal palynological techniques and were handled beyond the hydrofluoric acid stage using the method of Neves and Dale (1963)

After an initial examination it was clear that the majority of the Paleogene sediments in the area were barren of dinoflagellate cysts (see site reports, Chapter 3 , this volume). It was decided, therefore, to concentrate on the two holes at Site 400 , particularly Hole $400 \mathrm{~A}$ which proved an excellent sequence of sediments from the middle Miocene to Pleistocene, yielding good assemblages of dinoflagellate cysts. Hole 400 provided further samples from the Pleistocene to the Recent. This study conveniently divided into two parts (1) the erection of a dinoflagellate zonation of the Neogene and Quaternary, to assist in the dating of the recovered sediments and (2) an investigation of Pleistocene environments, particularly with reference to changes in the North Atlantic circulation.

\section{NEOGENE AND QUATERNARY ZONATION OF HOLES 400/400A}

Initially 27 productive samples from holes at Site 400 were included in a study of Neogene and Quaternary dinoflagellate biostratigraphy. Distributions of the recovered dinoflagellate cyst species and their ranges are shown in Figure 1. These data are used to erect a tentative fourfold informal zonation based largely upon the first uphole appearance of certain species. It must, however, at the moment remain speculative because of the sparse published information on Neogene dinoflagellates.

Zone $\mathrm{I}$ is characterized by the presence of Palaeocystodinium golzowense Alberti and Pentadinium taeniagerum Gerlach; because of poor recovery below Sample 30-1, 22-25 $\mathrm{cm}$ in Hole 400A, a true base cannot be defined.

The base of Zone II and Subzone IIa is, however, drawn at the first appearance of Bitectatodinium tepikiense Wilson, with Amiculosphaera umbracula Harland, Leptodinium aculeatum Wall and "Thalassiphora delicata" Williams and Downie emend. Eaton. It also marks the approximate extinction of Palaeocystodinium golzowense Alberti and Pentadinium taeniagerum Gerlach. Subzone IIb is recognized on the first appearance of Leptodinium patulum Wall with associated ?Pyxidiella simplex Harland. The following species also make their first appearance in Subzone IIb; Hystrichokolpoma cf. poculum Maier, Operculodinium crassum Harland, Operculodinium sp., Spiniferites septentrionalis Harland, and $S$. splendidus Harland. The species Cannosphaeropsis sp., Operculodinium sp., ?Pyxidiella simplex, and Wetzeliella sp. become extinct during Subzone IIb. The boundary between Zones I and II is of middle Miocene age and is placed at Sample 26-3, 49-53 cm, in Hole 400A.

The boundary between Zones II and III is of early Pliocene age and is drawn at Sample 13-3, 111-113 cm. Zone III is marked by the first appearance of Spiniferites mirabilis (Rossignol) Wall in association with Spiniferites $\mathrm{cf}$. pseudofurcatus Klumpp and Tectatodinium pellitum Wall. The species Nematosphaeropsis labyrinthea (Ostenfeld) Reid, Spiniferites belerius Reid, and the cyst of Protoperidinium subinerme Paulsen also make their first appearance in Zone III. 


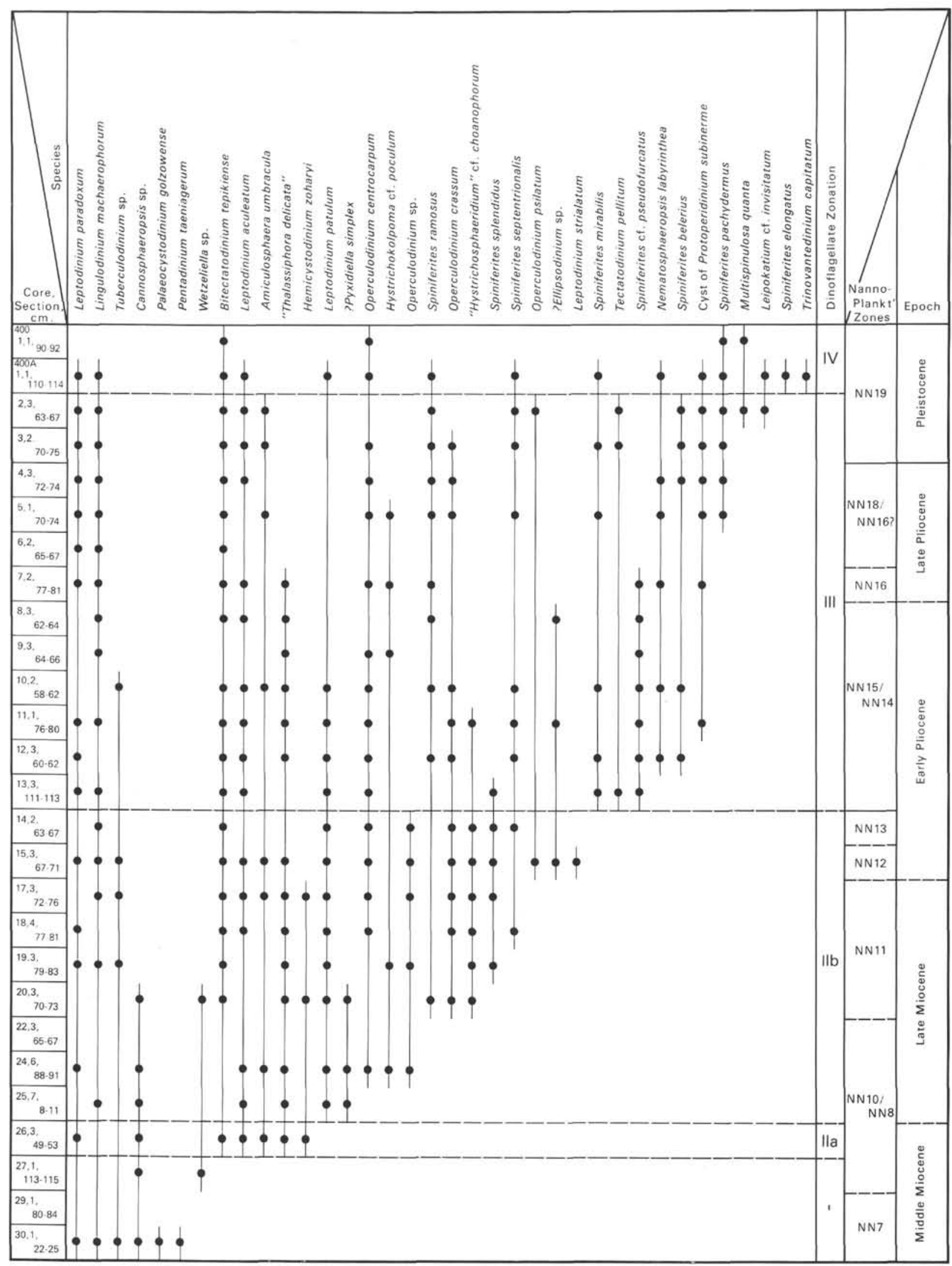

Figure 1. Range and distribution chart of dinoflagellate cysts recovered for the study of the Neogene dinoflagellate biostratigraphy of sediments from Holes 400/400A. Dots indicate presence. 
The species ?Ellipsodinium sp., Hystrichokolpoma cf. poculum Maier, "Hystrichosphaeridium'" cf. choanophorum Deflandre and Cookson, Operculodinium crassum Harland, Spiniferites cf. pseudofurcatus Klumpp, S. splendidus Harland, "Thalassiphora delicata"' Williams and Downie emend. Eaton, and Tuberculodinium sp. become extinct within Zone III.

The base of Zone IV is marked by the first appearance of Spiniferites elongatus Reid in association with Trinovantedinium capitatum Reid. It further marks the approximate extinction of Amiculosphaera umbracula Harland and Tectatodinium pellitum Wall. The base of Zone IV is of Pleistocene age and occurs at Sample 1-1, 110-114 cm in Hole 400A.

Further work on the additional 48 samples provided for the environmental study of the Pliocene/Pleistocene from Holes 400/400A supports the erection of Zone IV and places its base, with more precision, at Sample 2-3, 59-61 cm in Hole 400A. Trinovantedinium capitatum Reid was, however, found in three samples below this level and although Tectatodinium pellitum Wall becomes extinct at about this horizon Amiculosphaera umbracula Harland was found as high as Sample 1-1, 118-120 cm.

\section{Comparisons}

There is little published work on the dinoflagellate cysts of the Neogene with which to compare, but Habib (1971) described dinoflagellate cysts from sediments across the Miocene/Pliocene boundary at the Tabiano type section in Italy and figured, amongst others, Leptodinium patulum Wall, Pyxidiella sp., and Thalassiphora sp. cf. $T$. pelagica ("T. delicata" of this report).

Also in 1971 Baltes described brackish-water Pliocene dinoflagellate cysts from Romania. Although the assemblage appears peculiar either to the facies and/or area there are some similarities at generic level, i.e., the presence of Leptodinium, Thalassiphora, and Tectatodinium (?Leiosphaeridia and Chytroeisphaeridia of Baltes), to the present assemblage.

Williams (1975) in describing dinoflagellate cyst assemblages from Mesozoic and Cenozoic sediments on the Nova Scotian Shelf and Grand Banks erects an informal zonation. The uppermost three zones encompass sediments of middle Miocene to Pleistocene age and are similar to those described here. His Pentadinium laticinctum assemblage zone is characterized in part by $P$. laticinctum Gerlach, Spiniferites crassipellis (Deflandre and Cookson) Sarjeant, Systematophora ancyrea Cookson and Eisenack, and Tanyosphaeridium sp. A. It is of middle Miocene age. The Cannosphaeropsis sp. A assemblage zone is characterized in part by the dinoflagellate cyst species Cannosphaeropsis $\mathrm{sp}$. A, Lingulodinium machaerophorum (Deflandre and Cookson), Nematosphaeropsis balcombiana Delandre and Cookson, and Tuberculodinium vancampoae (Rossignol) Wall and is of late Miocene age. The youngest zone, the Artemisia-Taraxacum assemblage zone, is partly characterized by Hystrichosphaeridium pseudorecurvatum Morganroth, Operculodinium israelianum (Rossignol) Wall, Spiniferites membranaceus (Rossignol) Sarjeant, S. scabratus (Wall) Sarjeant, Tectatodinium pellitum Wall, and Thalassiphora delicata Williams and Downie and is
Pliocene/Pleistocene in age. The two youngest zones compare to Zones II and III of this account.

More recently Manum (1976) has published on Tertiary dinoflagellate cysts from the Norwegian-Greenland Sea, Leg 38 of the Deep Sea Drilling Project, and described the species Pentadinium taeniagerum Gerlach from samples dated as middle Miocene. He also records Thalassiphora delicata Williams and Downie from the late Oligocene to Miocene.

Costa and Downie (this volume) have recorded Bitectatodinium tepikiense Wilson, Leptodinium aculeatum Wall, Leptodinium patulum Wall, and Leptodinium strialatum Wall from their informal Zone VIII. They regard it as being similar to Zone I of Manum (1976), and I believe it may encompass Zones I and II of the present work.

\section{PLIO/PLEISTOCENE DINOFLAGELLATE CYSTS AND THEIR ENVIRONMENTS AT HOLES 400/400A}

Forty-nine samples of sediment from the Pliocene/ Pleistocene boundary to the Recent were examined to detail changes in the North Atlantic circulation as seen at Holes $400 / 400$ A. Figure 2 shows the distribution of the species recovered. Recently Reid and Harland (1977) have discussed the distributions of dinoflagellate cysts from Recent sediments in the North Atlantic area, and have concluded that they are controlled by latitude, depth, water mass, and sediment type, but not necessarily in that order. The present-day North Atlantic as it affects or is likely to affect the Bay of Biscay may be subdivided into four areas, characterized by differing cyst assemblages, i.e., the southern North Sea, the North Atlantic Drift, the East Atlantic, and the Moroccan (see fig. 1 and table 2 of Reid and Harland, 1977). Hence the Operculodinium centrocarpum/Bitectatodinium tepikiense species group of Figure 2 can be regarded as an indication of oceanic, temperate, North Atlantic conditions, the Spiniferites spp. (excluding $S$. mirabilis) as neritic, temperate, and offshore conditions, the Protoperidinium cysts as an indication of particular neritic, temperate or nearshore conditions, and the Leptodinium spp. species group as possibly indicating oceanic, sub-temperate/sub-tropical environments.

The cores from Site 400, late Pleistocene to Recent, reveal in a downhole sequence an upper assemblage that can be directly compared to the East Atlantic assemblage of Reid and Harland (1977) with rich assemblages containing significant proportions of Nematosphaeropsis labyrinthea (Ostenfeld) Reid and Spiniferites mirabilis (Rossignol) Sarjeant together with other North Atlantic oceanic indicators, e.g., Bitectatodinium tepikiense Wilson and Operculodinium centrocarpum (Deflandre and Cookson) Wall. These were recovered from Samples 1-1, 40-42 cm to $1-1,110-112 \mathrm{~cm}$. This assemblage was preceded by one characterized by rich assemblages with high proportions of Protoperidinium cysts which may be compared with the southern North Sea assemblages of Reid and Harland (1977), i.e., in Samples 1-2, $5-7 \mathrm{~cm}$ to $1-4,66-68 \mathrm{~cm}$. The assemblage may indicate shallower water, and that the North Atlantic Current was flowing in a more southerly position than at present, possibly allowing cold polar water into lower latitudes (McIntyre et al., 1972). Below this assemblage there occur several samples, $1-4,115-117 \mathrm{~cm}$ to $1-6,95-96 \mathrm{~cm}$, which reveal alternating high and low percentages of Protoperidinium cysts but with low numbers of individuals. This assemblage may be 


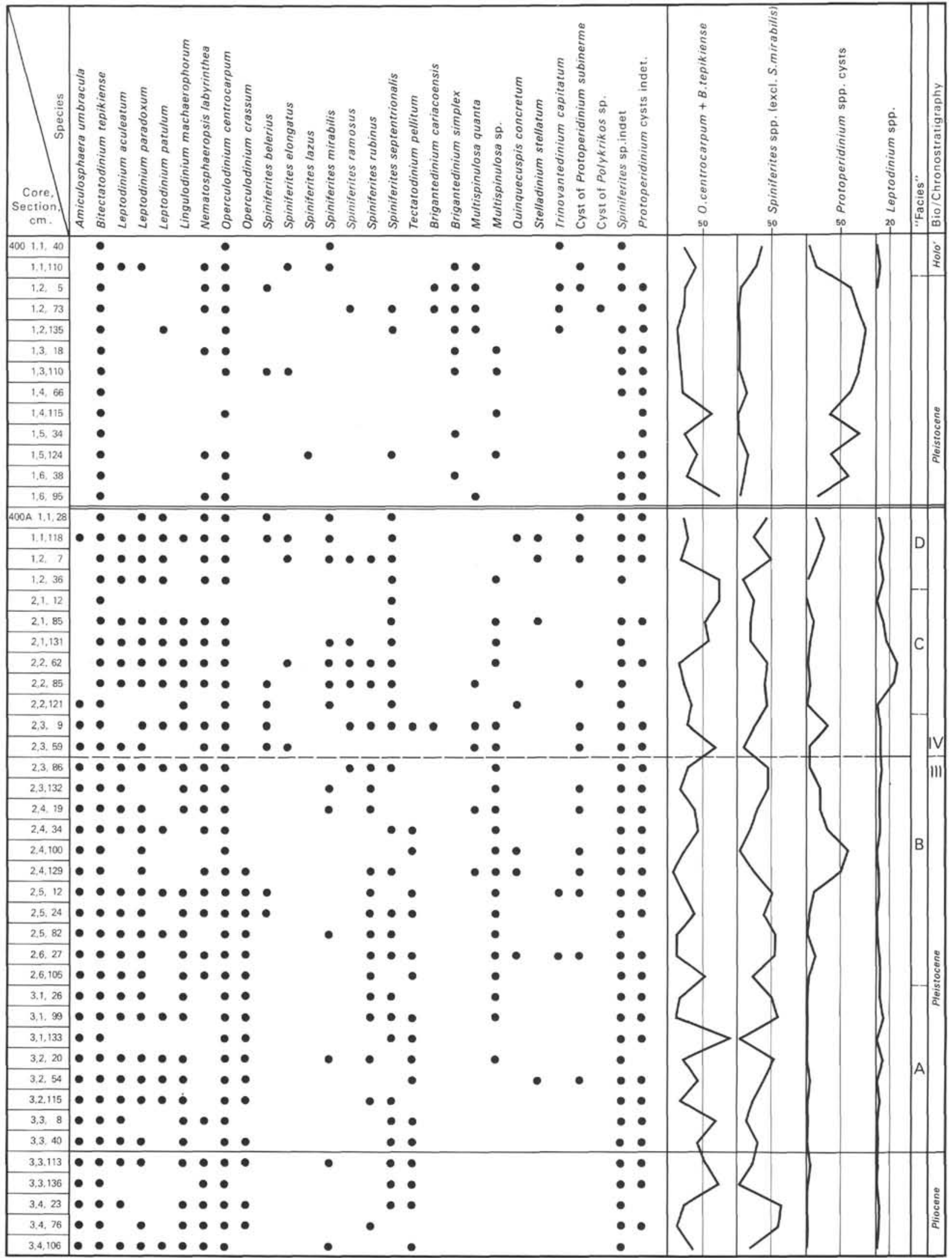

Figure 2. Distribution chart of dinoflagellate cysts recovered for the study of environments, from Pliocene-Pleistocene sediments at Holes 400/400A. Dots indicate presence, letters $A$ to $D$ in the "facies" column are referred to in the text. 
interpreted as indicating unfavorable environments and possibly a severe climate. The presence of Nematosphaeropsis labyrinthea (Ostenfeld) Reid and the increased proportions of Bitectatodinium tepikiense Wilson and Operculodinium centrocarpum (Deflandre and Cookson) Wall, indicate some oceanic influence.

In the case of cores from Hole 400A, Pliocene to early Pleistocene, new species and some species of stratigraphic importance make their first downhole appearance, but, in identifying environments, the graph of the various species groups can still be used. In downhole order, Samples 1-2 $28-30 \mathrm{~cm}$ to $1-2,36-38 \mathrm{~cm}$ contain an assemblage comparable to the East Atlantic assemblage of Reid and Harland (1977) with significant percentages of Nematosphaeropsis labyrinthea (Ostenfeld) Reid and Spiniferites mirabilis (Rossignol) Sarjeant, ("Facies"' D, Figure 2).

Samples 2-1, 12-14 cm to 2-2, 121-122 cm demonstrate a rise and fall in the percentage of Leptodinium spp. (see "Facies"' C, Figure 2) which may indicate a deepening and subsequent shallowing of the ocean and/or an increase and decrease of temperature, with the area being covered by a dinoflagellate cyst assemblage comparable to the Moroccan assemblages of Reid and Harland (1977).

Samples 2-3, 9-11 $\mathrm{cm}$ to $2-6,105-107 \mathrm{~cm}$ show a marked rise followed by a decline in the proportion of peridiniacean cysts which is interpreted as indicating the presence of a "southern North Sea" type of assemblage, with cooler and shallower water ("Facies" B, Figure 2).

Finally from Samples 3-1, 26-28 cm to $3-4,106-108 \mathrm{~cm}$ the assemblage appears to be comparable with the Intermediate Neritic assemblage of Reid and Harland (1977), i.e., found in the North Sea at the present time. It contains significant proportions of the oceanic indicators Bitectatodinium tepikiense Wilson and Operculodinium centrocarpum (Deflandre and Cookson) Wall together with Spiniferites spp., characterizing more neritic situations ("Facies" A, Figure 2). Between Samples 3-1, 26-28 cm and $3-3,8-10 \mathrm{~cm}$ there is a slight increase in the percentage of Leptodinium spp. which may indicate a deepening or an influence of southerly Atlantic water. This section is also marked by the occasional high percentage of such species as Operculodinium crassum Harland (38\%) in Sample 3-2, $115-117 \mathrm{~cm}$, Tectatodinium pellitum Wall (14\%) in Sample 3-3, 136-138 cm, and Nematosphaeropsis labyrinthea (Ostenfeld) Reid (33\%) in Sample 3-4, 106-108 cm. The significance of these unusually high percentages is not known.

It is of particular interest that the Pliocene/Pleistocene boundary, based on calcareous micro-organisms, was not recognized by using either the stratigraphical ranges of the recovered dinoflagellate cyst species or by an examination of the environments of the time.

\section{SYSTEMATIC DESCRIPTIONS}

Forty-four dinoflagellate cyst species were identified; all of the species are listed below with descriptions and/or remarks where appropriate. The illustrated specimens have been designated with an MPK number and registered within the Palynological Collections of the Institute of Geological Sciences at Leeds.

Division PYRRHOPHYTA Pascher, 1914

Class DINOPHYCEAE Fritsch, 1929

Order PERIDINIALES Haeckel, 1894

\section{Family GONYAULACACEAE Lindemann, 1928}

Genus AMICULOSPHAERA gen. nov.

Derivation of Name: Latin - amiculum, a mantle, cloak; sphaera, globe, sphere; with reference to the cloak-like nature of the periphragm surrounding the epitract.

Diagnosis: Cavate cyst with an epitractal, cingular, and partly hypotractal pericoel formed by the separation of the periphragm from the endophragm. Periphragm forms an outer "cloak-like" covering to the epitract that may or may not carry traces of a paratabulation, but which is attached to the hypotract within the post-cingular plate series. Periphragm supported at the apex by an apical process that is confluent with the periphragm. Tabulation gonyaulacacean, the archeopyle pre-cingular formed by the loss of 3 " in both the endoblast and periblast.

Type Species: Amiculosphaera umbracula sp. nov., Pleistocene, Bay of Biscay.

Remarks: This genus is similar to Erikania Morgenroth 1966 but differs in that the periphragmal membrane is developed only over the epitract and is supported by a single apical process.

Amiculosphaera umbracula sp. nov.

(Plate 1, Figures 11-14, 22, 23; Plate 2, Figures 1-3)

Derivation of Name: Latin-umbraculum, a parasol, with reference to the umbrella-like apical process that supports the periphragm.

Diagnosis: Cavate cyst with an epitractal pericoel supported apically by a single flaring apical process. Wall layers on the hypotract closely adpressed, except towards the cingulum where separation is initiated. Endoblast spherical to ovoid sometimes with a small apical boss. Periblast inflated, and ovoid, the epitract being larger and more expanded than the hypotract. Endophragm smooth, periphragm smooth to micropunctate. Tabulation appears to be gonyaulacacean, $? 4^{\prime}, 6^{\prime \prime}, 6 \mathrm{c}, ?^{\prime \prime \prime}, 1^{\prime \prime \prime}$, the archeopyle is pre-cingular formed by the loss of $3^{\prime \prime}$ in both wall layers.

Holotype: MPK 1638, (Plate 2, Figures 1-3).

Type Locality: Bay of Biscay, Sample 400A-2-4, 100-102 cm.

Dimensions: Holotype: Length of endoblast $56.0 \mu \mathrm{m}$; breadth $46.0 \mu \mathrm{m}$; Length of periblast $80.0 \mu \mathrm{m}$; breadth $86.0 \mu \mathrm{m}$. Range: Length of endoblast 36.0-56.0 $\mu \mathrm{m}$; breadth $44.0-70.0 \mu \mathrm{m}$; Length of periblast $64.0-80.0 \mu \mathrm{m}$; breadth $70.0-104.0 \mu \mathrm{m}$. Eleven specimens measured.

Description: Epitractal pericoel and "cloak-like" periphragm is characteristic of this genus and the flared, almost from the process base, apical process is characteristic of the species. In addition to the apical process, there are four gonal protuberances at the antapical plate boundary which are made up of both wall layers (Plate 1, Figures 14, 22). The apical, precingular, and cingular plate series are particularly conspicuous, and on the margin of the periblast archeopyle the suture between paraplates $3 \mathrm{c}$ and $4 \mathrm{c}$ is often marked by a prominent peak (Plate 1, Figure 23; Plate 2, Figure 3). The cingulum takes the form of a laevorotatory helicoid, is not indented, and may be displaced by up to its own width; the sulcus is devoid of plates but the arrangement of Plates $1^{\prime}, 4^{\prime}$ and the anterior margin of the ? anterior sulcal vplate is often visible (Plate 2,Figure 2). Archeopyle is usually conspicuous especially within the periblast where a large ?broad pentagonal plate $3^{\prime \prime}$ has been lost (Plate 2, Figures 1,3). On the endoblast, however, the typical elongate pentagonal pre-cingular archeopyle shape is discernible. The endoblast operculum may sometimes be found within the cavity of the endoblast.

Remarks: Similarities and differences to the monospecific genus Erikania Morgenroth have already been noted. The distinct morphology of Amiculosphaera umbracula sp. nov. distinguish it from other described cysts.

Occurrence: Observed in sediments of late Miocene to early Pleistocene age from Holes 400/400A.

Genus BITECTATODINIUM Wilson, 1973

Bitectatodinium tepikiense Wilson, 1973.

Genus CANNOSPHAEROPSIS O. Wetzel emend. Williams and Downie, 1966

\section{Cannosphaeropsis sp}

(Plate 3, Figure 17)

Description: A small chorate cyst (22.0-28.0 $\mu \mathrm{m}$ long; $22.0-24.0 \mu \mathrm{m}$ broad; processes $10.0-14.0 \mu \mathrm{m}$ long), with smooth to micropunctate, twolayered cyst wall. Processes numerous, hollow, erect with birfurcate or trifurcate distal extremities, linked by trabeculae that are both rod and 
ribbon-like. No tabulation observed or exhibited by process or trabeculae arrangement. Archeopyle pre-cingular.

\section{Genus ELLIPSODINIUM Clarke and Verdier, 1967}

\section{?Ellipsodinium sp.}

(Plate 2, Figures 17, 18)

Description: Small ( $36.0 \mu \mathrm{m}$ long; $32.0 \mu \mathrm{m}$ broad) cyst made up of two adpressed wall layers. Periphragm makes up the reticulate ornamentation that only appears similar to a tabulation in the sulcal area. Fields of the reticulation are delimited by low, smooth membranes (up to $3.0 \mu \mathrm{m}$ high) within which there may be a microvermiculate ornamentation. Archeopyle pre-cingular presumably formed by the loss of paraplate ? $3^{\prime \prime}$, (Plate 2, Figure 17).

Remarks: This cyst most closely compares with Ellipsodinium regulosum Clarke and Verdier, 1967, but differs in not possessing the elongate reticulation or reflecting a tabulation. It is questionably assigned to Ellipsodinium because of its possession of a reticulate ornamentation and precingular archeopyle. It also resembles Leptodinium incompositum (Drugg) Lentin and Williams, 1973, which differs in possessing a well-defined tabulation.

\section{Genus HEMICYSTODINIUM Wall, 1967}

Hemicystodinium zoharyi (Rossignol) Wall, 1967

\section{Genus HYSTRICHOKOLPOMA Klumpp emend. Williams and Downie, 1966}

\section{Hystrichokolpoma cf. poculum Maier, 1958}

(Plate 2, Figure 16)

Description: A cyst with a spherical to ovoid central body made up of two closely adpressed wall layers, with a micropunctate ornamentation. Processes are hollow, made up of periphragm, and with the exception of the antapical, tubular with flared, distal tips and an irregular margin. The processes are up to one-half the cyst diameter in length and the micropunctate ornamentation on the process shafts often gives them a striate appearance. Cyst does not possess cingular processes but does carry 1-3 narrow flexuous, sulcal processes that are flared and open distally. The antapical process is larger than all the others, is closed distally, but significantly does not carry distal tubules. All the processes are intratabular and reflect a ?', $5^{\prime \prime}, 0 \mathrm{c}, 0-3 \mathrm{~s}, 5^{\prime \prime \prime}, 1^{\prime \prime \prime}$ tabulation. The archeopyle is apical.

The illustrated specimen has a length of $58.0 \mu \mathrm{m}$, a breadth of $56.0 \mu \mathrm{m}$, and a maximum process length (excluding the antapical process of $50.0 \mu \mathrm{m}$ length) of $32.0 \mu \mathrm{m}$.

Remarks: This species is characterized by the lack of cingular processes which differentiates it from all other described species of Hystrichokolpoma, but by virtue of its process morphology is most closely comparable to $H$. poculum which was originally described from the middle Miocene (Maier, 1958).

Genus HYSTRICHOSPHAERIDIUM Deflandre emend. Davey and Williams, 1966

\section{"Hystrichosphaeridium" cf. choanophorum Deflandre and Cookson, 1955 \\ (Plate 3, Figures 5-7)}

Description: A small, chorate, spheroidal cyst ( 34.0 to $38.0 \mu \mathrm{m}$ in length; $30.0-34.0 \mu \mathrm{m}$ broad) made up of two closely adpressed wall layers. The processes are long (20.0-24.0 $\mu \mathrm{m}$ in length), tubular with a flared distal tip. Some variation is apparent as in some specimens the process flaring can be conspicuous and similar to that found in $H$. choanophorum (Deflandre and Cookson, 1955, fig. 23-29). The process tip margins carry spines that may be short or long (i.e., 0.5-3.0 $\mu \mathrm{m}$ ), numerous or few and sometimes recurved (Plate 3, Figure 6). Archeopyle unknown.

Remarks: This cyst has previously been described as $H$. pseudorecurvatum Morgenroth by Williams (1974) and may be confused with $H$. asterium Eaton, which differs in having definite stellate distal extremities to the processes. Work is currently in progress (Harland and Hill, in preparation) to re-evaluate " $H$." cf. choanophorum.

Genus LEPTODINIUM Klement emend. Sarjeant, 1969 Leptodinium aculeatum Wall, 1967 (Plate 1, Figures 17, 18). Leptodinium paradoxum Wall, 1967 (Plate 1, Figures 19, 20).
Leptodinium patulum Wall, 1967 (Plate 1, Figures 5-8).

Leptodinium strialatum Wall, 1967.

Genus LINGULODINIUM Wall emend. Wall et al., 1973

Lingulodinium machaerophorum (Deflandre and Cookson) Wall, 1967.

Genus NEMATOSPHAEROPSIS Deflandre and CooKson emend. Williams and Downie, 1968

Nematosphaeropsis labyrinthea (Ostenfeld) Reid, 1974 (Plate 1, Figure 21).

Genus OPERCULODINIUM Wall, 1967

Operculodinium centrocarpum (Deflandre and Cookson) Wall, 1967.

Operculodinium crassum sp. nov.

(Plate 2, Figures 12-14)

Derivation of Name: Latin-crassus, thick, with reference to the thick wall of this species.

Diagnosis: Spherical chorate cyst made up of two closely adpressed wall layers. Wall is thick (up to $4.0 \mu \mathrm{m}$ ), with the bulk of it being periphragm. Surface ornament microgranulate or micropunctate, but in optical section the wall layer appears spongy. Processes short $(1 / 5-1 / 8$ cyst diameter), numerous, conical with a flared distal tip. Archeopyle pre-cingular presumably formed by the loss of plate $3^{\prime \prime}$.

Holotype: MPK 1642 (Plate 2, Figures 12-14).

Type Locality: Bay of Biscay, Sample 400A-12-3, 60-62 cm.

Dimensions: Holotype: Length, exclusive of processes, $62.0 \mu \mathrm{m}$; breadth $62.0 \mu \mathrm{m}$; maximum process length $8.0 \mu \mathrm{m}$; wall thickness $4.0 \mu \mathrm{m}$. Range: Length, 54.0-74.0 $\mu \mathrm{m}$; breadth 50.0-68.0 $\mu \mathrm{m}$; process length 8.0$11.0 \mu \mathrm{m}$; wall thickness $2.0-4.0 \mu \mathrm{m}$. Seven specimens measured.

Description: A species of Operculodinium with a characteristically thick wall layer, at least twice the thickness of any previously described species (Plate 2, Figure 13). The exact nature of the wall structure and ornament is difficult to see and would benefit from study with a transmission and scanning electron microscope. The processes carry the same microgranulation and punctation on their shafts as seen on the cyst body and have bifid or flared tips.

Remarks: This species is most similar to Operculodinium israelianum (Rossignol) Wall from which it differs in possessing a thick wall. The process structure of the two species is similar, being short and conical, but $O$. crassum differs in that the process morphology is variable and not so consistent as in $O$. israelianum (Wall, 1967). This species is probably cospecific with Operculodinium sp. I of Manum (1976).

Occurrence: Observed in late Miocene to early Pleistocene sediments from Hole 400A.

Operculodinium psilatum Wall, 1967.

\section{Operculodinium sp. \\ (Plate 3, Figure 16)}

Remarks: A small ( $44.0 \mu \mathrm{m}$ diameter), spherical species characterized by small and conical processes. The processes are hollow and are, in length, less than $1 / 12$ the cyst diameter. They appear to have micropunctate bases but otherwise they and the wall layers are smooth. Archeopyle is pre-cingular presumably formed by the loss of paraplate $3^{\prime \prime}$.

\section{Genus PENTADINIUM Gerlach, 1961}

Pentadinium taeniagerum Gerlach, 1961 (Plate 3, Figures 3, 4).

Genus SPINIFERITES Mantell emend. Sarjeant, 1970

Spiniferites belerius Reid, 1974.

Spiniferites elongatus Reid, 1974.

Spiniferites lazus Reid, 1974.

Spiniferites mirabilis (Rossignol) Sarjeant, 1970 (Plate 1, Figures 1-4).

Spiniferites pachydermus (Rossignol) Reid, 1974.

\section{Spiniferites cf. pseudofurcatus (Klumpp) Sarjeant, 1970}

(Plate 2, Figures 19, 20)

Remarks: This species differs from $S$. pseudofurcatus in possessing membranous processes especially on the cingulum and hypotract, that may be linked distally. This species is also characterized by a separation of the wall layers beneath the processes giving the appearance of a hollow, somewhat bulbous process base (Plate 2, Figure 20). In other respects the size and 
nature of the structure of the distal tips are very similar. Particularly interesting is the seemingly restricted range of the species, in the present study, from early to late Pliocene.

Spiniferites ramosus (Ehrenberg) Mantell, 1854.

Spiniferites rubinus (Rossignol) Sarjeant, 1970

(Plate 2, Figures 4-11)

Description: An ovoid cyst made up of two closely adpressed wall layers. Periphragm micropunctate and makes up the processes and sutural membranes. Tabulation unclear, but plate areas $4^{\prime}$ and $1^{\prime \prime \prime \prime}$ may be recognized. The cingulum and sulcus are also usually conspicuous, but do not exhibit individual plates. The sulcus appears broad and the cingulum is a laevorotatory helicoid, not indented and planar or displaced by one-half of its width. Processes, when recognizable as such, are gonal and membranous and are most conspicuous in the apical, antapical, cingular, and sulcal areas, and are somewhat flexuous with petaloid tips (Plate 2, Figures 4, 5). Some specimens exhibit a morphology where the cyst appears to carry many membranes especially in the areas described (Plate 2, Figures 7,10). The sulcus is so broad and carries such high membranes on its circumference that the cyst often appears to be carrying membranes only around its margin. It is possible, however, that membranes are not developed between the sulcus and the adjacent pre- and post-cingular plates. In these forms some of the non-membranous processes appear as small protuberances. Complex boxlike processes also occur at the apex of the sulcus and in the position of the posterior intercalary plate (Plate 2, Figures 8 and 11). Some of the more complex membranous processes carry small spines. In specimens that exhibit more obvious processes, those in the cingular region are erect, simple, slender, and conical. The archeopyle is pre-cingular formed by the loss of plate $3^{\prime \prime}$.

Dimensions: Range: Length of cyst excluding processes or membranes 46.0-54.0 $\mu \mathrm{m}$; breadth 38.0-46.0 $\mu \mathrm{m}$; maximum process length or membrane height $10.0-12.0 \mu \mathrm{m}$.

Remarks: A description of this species is included here because, since its first description by Rossignol (1964), it has not, to the writer's knowledge, been recorded in literature.

Spiniferites septentrionalis Harland, 1977.

Spiniferites splendidus sp. nov.

(Plate 3, Figures 1, 2)

Derivation of Name: Latin—splendidus, splendid, with reference to the large and flamboyant morphology.

Diagnosis: Large spherical to ovoid cyst made up of two closely adpressed wall layers, the periphragm of which is smooth to micropunctate. Processes are large, long, erect, and of two types. The first are membranous box-shaped and carry smaller tubular spines with bi- or trifid tips; these are prevalent on the sulcus and the pre-cingular plate series, on the cingulum, the ?posterior intercalary position and at the antapex (Plate 3, Figure 2). The second are gonal, long, thin, tubular, and have marked bifurcate or trifurcate terminations with bifid distal tips (Plate 3, Figure 1). Tabulation typical of the genus, archeopyle pre-cingular formed by loss of plate $3^{\prime \prime}$.

Holotype: MPK 1647 (Plate 3, Figure 1).

Type Locality: Bay of Biscay, Sample 400A-15-3, 67-71 cm.

Dimensions: Holotype: Length, excluding processes $70.0 \mu \mathrm{m}$; breadth $74.0 \mu \mathrm{m}$, maximum process length $42.0 \mu \mathrm{m}$. Range: Length $62.0-84.0 \mu \mathrm{m}$; breadth 52.0-76.0 $\mu \mathrm{m}$, process length 22.0-44.0 $\mu \mathrm{m}$. Eight specimens measured.

Description: Some specimens of this species are broader than long and exhibit some separation of the wall layers beneath the processes giving rise to bulbous process bases. The cyst is characterized, however, by its large size and by the distinctive morphology of the processes. The membranous processes are particularly conspicuous especially those in the posterior intercalary position (Plate 3, Figure 2). The tabulation is outlined by low ridges or membranes which are confluent with the process structure.

Remarks: The size and process morphology of this cyst distinguishes it from all other species of Spiniferites. It is most similar to $S$. mirabilis (Rossignol) Sarjeant from which it differs in being larger, and in possessing many flamboyant membranous processes.

Occurrence: Observed in late Miocene to early Pliocene sediments from Hole 400A.

Genus TECTATODINIUM Wall, 1967

Tectatodinium pellitum Wall, 1967 (Plate 1, Figures 9, 10).

Genus THALASSIPHORA Eisenack and Gocht emend. Gocht, 1968
"Thalassiphora delicata" Williams and Downie emend. Eaton, 1976 (Plate 2, Figure 15)

Description: Spherical, ovoid, membranous cavate cyst. Wall layers are micropunctate. The periphragm may carry traces of a tabulation outlined by low ridges, but the tabulation and the structure of this cyst have not been deciphered. Occasional membranous processes have been noted in some specimens seemingly supporting the periphragm but they are never conspicuous. Archeopyle possibly pre-cingular.

Remarks: This cyst is probably cospecific with Thalassiphora sp. cf.T. pelagica as figured by Habib (1971), T. delicata by Williams (1974; p. 132) and with $T$. delicata by Williams and Brideaux (1975, pl. 13, fig. 6). It is remarkably similar to $T$. delicata Williams and Downie emend. Eaton, but because the structural nature and the orientation of the cyst have not been deciphered it is cited in inverted commas.

\section{Family PERIDINIACEAE Ehrenberg, 1832}

Genus BRIGANTEDINIUM Reid, 1977

Brigantedinium cariacoensis (Wall) Reid, 1977.

Brigantedinium simplex (Wall) Reid, 1977.

\section{Genus LEIPOKATIUM Bradford, 1975}

\section{Leipokatium cf. invisitatum Bradford, 1975 (Plate 1, Figure 15)}

Remarks: Occasional specimens of Protoperidinium cysts that can be attributed to this species were seen. I am not fully convinced of the validity of this identification since the specimens observed could equally be distorted specimens of the genus Lejeunia Gerlach emend. Lentin and Williams, 1975.

Genus MULTISPINULA Bradford, 1975

Multispinula quanta Bradford, 1975.

\section{Multispinula sp.}

Remarks: Multispinula sp. is applied to a small variety of $M$. quanta Bradford, 1975 that possesses small and delicate processes (i.e., approximately $28.0 \mu \mathrm{m}$ in diameter, with processes approximately $4.0 \mu \mathrm{m}$ long), about one-half the size of the holotype of $M$. quanta (see Bradford, 1975 , p. 3069).

Genus PALAEOCYSTODINIUM Alberti, 1961

Palaeocystodinium golzowense Alberti, 1961.

Genus PYXIDIELLA Cookson and Eisenack, 1958

?Pyxidiella ef. scrobiculata (Deflandre and Cookson) Cookson and Eisenack, 1958

(Plate 3, Figures 10, 11)

Remarks: This specimen is most like ?P. cf. scrobiculata (Deflandre and Cookson) Cookson and Eisenack especially in size, but it does differ in the character of the ornament (Plate 3, Figures 10, 11).

\section{?Pyxidiella simplex sp. nov.}

(Plate 3, Figures 12-15)

Derivation of Name: Latin, simplex, simple, in relation to its uncomplicated morphology.

Diagnosis: Ovoid to rounded pentagonal cyst made up of two wall layers closely adpressed, and carrying a microgranulate, granulate, conate, or spinate to foveolate ornamentation. Wall thick $(2.0 \mu \mathrm{m})$ and may be drawn out into a rounded apical boss. Tabulation not present, archeopyle probably intercalary presumably formed by the loss of plate $2 \mathrm{a}$.

Holotype: MPK 1655 (Plate 3, Figure 12).

Type Locality: Bay of Biscay, Sample 400A-24-6, $88-91 \mathrm{~cm}$.

Dimensions: Holotype: Length $36.0 \mu \mathrm{m}$; breadth $30.0 \mu \mathrm{m}$; Range: Length 32.0-46.0 $\mu \mathrm{m}$; breadth 28.0-38.0 $\mu \mathrm{m}$. Four specimens measured.

Description: Cyst shape is variable, some specimens showing a clearly pentagonal outline (Plate 3, Figure 12) whilst others are ovoid (Plate 3, Figures 13-15). The ornamentation is often difficult to decipher, but probably both negative and positive elements are present; some specimens carry distinct cones or granules. The archeopyle shape is of interest as it 
suggests the quadra-type peridinacean plan, this together with position on the cyst indicate an archeopyle of the intercalary type (Plate 3, Figure 12).

Remarks: This cyst is most easily attributed to the genus Pyxidiella Cookson and Eisenack and is similar to $P$. scrobiculata (Deflandre and Cookson) Cookson and Eisenack, 1958, from which it differs in not possessing such a coarse positive ornament, in being half the size and in sometimes possessing a pentagonal outline.

Occurrence: Observed in late Miocene sediments from Hole 400A.

Genus QUINQUECUSPIS Harland, 1977

Quinquecuspis concretum (Reid) Harland, 1977.

Genus STELLADINIUM Bradford, 1975

Stelladinium stellatum (Wall) Reid, 1977.

Genus WETZELIELLA Eisenack emend. Williams and Downie, 1966

\section{Wetzeliella sp.}

(Plate 3, Figure 9)

Remarks: Occasional specimens of this genus were encountered in the preparations but never in sufficient numbers or preserved well enough to warrant description. The illustrated specimen gives some indication, however, of the general morphology.

Cyst of Protoperidinium subinerme (Paulsen) Loeblich III 1969 (Plate 1, Figure 16).

\section{Order GYMNODINIALES Lemmermann, 1910}

Family POLYKRIKACEAE Kofoid and Swezy, 1921

Cyst of Polykrikos sp.

Family PYROPHACACEAE Lindemann, 1928

Genus TUBERCULODINIUM Wall, 1967

\section{Tuberculodinium sp. \\ (Plate 3, Figure 8)}

Remarks: Occasional poorly preserved specimens attributable to this genus were recorded, the best of which is illustrated.

\section{ACKNOWLEDGMENTS}

I would like to thank Miss Jane Hill for her excellent preparation of the samples and also Professor C. Downie and Drs. L. I. Costa and R. J. Davey for their constructive comments of the manuscript. The author publishes with the approval of the Director, Institute of Geological Sciences, London. The author would also like to acknowledge the interest shown by the Department of Energy in funding participation in the Deep Sea Drilling Project.

\section{REFERENCES}

Baltes, N., 1971. Pliocene dinoflagellata and acritarcha in Romania. In Farinacci, A., (Ed.). Proceedings of the Second International Planktonic Conference, v. 1, p. 1-16.

Bradford, M. R., 1975. New dinoflagellate cyst genera from the recent sediments of the Persian Gulf, Canadian Journal of Botany, v. 53, p. 3064-3074.

Deflandre, G. and Cookson, I. C., 1955. Fossil microplankton from Australian Late Mesozoic and Tertiary sediments, Australian Journal of Marine and Freshwater Research, v. 6, p. $242-313$

Habib, D., 1971. Dinoflagellate stratigraphy across the Miocene-Pliocene boundary, Tabiano stratotype section. In Farinacci, A. (Ed.). Proceedings of the Second Planktonic Conference, v. 1, p. 591-598.

Maier, D., 1959. Planktonuntersuchungen in tertiären und quartären marinen Sedimenten. Ein Beitrag zur Systematik, Stratigraphie und Ökologie der Coccolithophorideen, Dinoflagellaten und Hystrichosphaerideen vom Oligozän bis zum Pleistozän, Neues Jarbuch Geologie und Paläontologie, Abh., v. 107 , p. $278-340$.

Manum, S. B., 1976. Dinocysts in Tertiary Norwegian-Greenland Sea sediments (Deep Sea Drilling Project Leg 38), with observations on palynomorphs and palynodebris in relation to environments. In Talwani, M., Udintsev, G., et al. Initial Reports of the Deep Sea Drilling Project, v. 38: Washington (U.S. Government Printing Office), p. 897-919.

McIntyre, A., Ruddiman, W. F., and Jantzen, R., 1972. Southward penetrations of the North Atlantic Polar Front: faunal and floral evidence of large scale surface water mass movements over the last 225,000 years, Deep-Sea Research, v. 19, p. 6177.

Neves, R. and Dale, B., 1963. A modified filtration system for palynological preparations, Nature, London, v. 198, p. 775-776.

Reid, P. C., 1974. Gonyaulacacean dinoflagellate cysts from the British Isles, Nova Hedwigia, v. 25, p. 579-637.

Reid, P. C. and Harland, R., 1977. Studies of Quaternary dinoflagellate cysts from the North Atlantic, American Association of Stratigraphic Palynologists, Contribution Series, v. $5 \mathrm{a}, \mathrm{p} \cdot 155-175$.

Wall, D., 1967. Fossil microplankton in deep-sea cores from the Caribbean Sea, Palaeontology, v. 10, p. 95-123.

Williams, G. L., 1975. Dinoflagellate and spore stratigraphy of the Mesozoic-Cenozoic, offshore eastern Canada, Geological Survey of Canada, Paper 74-30, v. 2, p. 107-161.

Williams, G. L. and Brideaux, W. W., 1975. Palynologic analyses of Upper Mesozoic and Cenozoic rocks of the Grand Banks, Atlantic continental margin, Geological Survey of Canada, Bulletin 236, p. 1-163. 
APPENDIX

List of Samples Prepared and Examined for Cenozoic Dinoflagellate Cysts (asterisks indicate barren samples)

\section{Hole 399}

Core 1, Section 4, 60-62 cm

Core 1 , Section $4,62-64 \mathrm{~cm}$

\section{Hole 400}

Core 1, Section 1, 40-42 cm

Core 1, Section 1, 90-92

Core 1, Section 1, 110-112

Core 1, Section 2, 5-7

Core 1, Section 2, 73-75

Core 1, Section 2, 135-137

Core 1, Section 3, 18-20

\section{Hole 400A}

Core 1 , Section $1, \quad 28-30 \mathrm{~cm}$

Core 1, Section 1, 110-114

Core 1, Section 1, 118-120

Core 1, Section 2, 7-8

Core 1, Section 2, 36-38

Core 2, Section 1, 12-14

Core 2, Section 1, 85-87

Core 2, Section 1, 131-133

Core 2, Section 2, 62-64

Core 2, Section 2, 85-87

Core 2, Section 2, 121-122

Core 2, Section 3, 9-11

Core 2, Section 3, 59-61

Core 2, Section 3, 63-67

Core 2, Section 3, 86-88

Core 2, Section 3, 132-134

Core 2, Section 4, 19-21

Core 2, Section 4, 34-36

Core 2, Section 4, 100-102

Core 2, Section 4, 129-131

Core 2, Section 5, 12-14

Core 2, Section 5, 24-26

Core 2, Section 5, 82-84

Core 2, Section 6, 27-29

Core 2, Section 6, 105-107
Core 3, Section 3, 110-112 cm

Core 1, Section 3, 66-68

Core 1, Section 3, 115-117

Core 1, Section 5, 34-36

Core 1, Section 5, 124-126

Core 1, Section 6, 38-40

Core 1, Section 6, 95-96

Core 3, Section 1, 26-28

Core 3, Section 1, 99-101

Core 3, Section 1, 133-135

Core 3, Section 2, 20-22

Core 3, Section 2, 54-56

Core 3, Section 3, 70-75

Core 3, Section 2, 115-117

Core 3 , Section $3, \quad 8-10$

Core 3, Section 3, 40-42

Core 3, Section 3, 113-115

Core 3, Section 3, 136-138

Core 3, Section 4, 23-25

Core 3, Section 4, 76-78

Core 3, Section 4, 106-108

Core 4, Section 3, 72-74

Core 5, Section 1, $70-74 \mathrm{~cm}$

Core 6, Section 2, 65-67

Core 7, Section 2, 77-81

Core 8, Section 3, 62-64

Core 9, Section 3, 64-66

Core 10, Section 2, 58-62

Core 11 , Section 1, 76-80

Core 12, Section 3, 60-62

Core 13, Section 3, 111-113

Core 14, Section 2, 63-67
Core 15, Section 3, 67-71

Core 17, Section 3, 72-76

Core 18 , Section $4,77-81$

Core 19, Section 3, 79-83

Core 20, Section 3, 70-73

Core 22, Section 3, 65-67*

Core 24, Section 6, 88-91

Core 24, Section 7, 8-11

Core 26, Section 3, 49-53

Core 27, Section 1, 113-115

Core 29, Section 1, 80-84*

Core 30 , Section 1, 22-25

Core 35, Section 3, 93-95*

Core 36, Section 2, 42-46

Core 37, Section 3, 67-70

Core 38, Section 1, 138-140*

Core 39, Section 2, 61-66*

Core 39, Section 1, 90-92*

Core 40 , Section 1, 20-22

\section{Hole 401}

Core 1 , Section $3,75-77 \mathrm{~cm}^{*}$

Core 2, Section 1, 34-36

Core 3, Section 1, 2-4*

Core 4, Section 0, core-catcher

Core 5, Section 2, 92-95* sample*
$92-95^{*}$
$56-60^{*}$

Core 6, Section 2, 56-60*

Core 7, Section 3, 47-50*

Core 8, Section 3, 74-77*

\section{Hole 402}

Core 1, Section 2, $86-89 \mathrm{~cm}$

Core 2, Section 1, 41-43

\section{Hole 402A}

Core 1, Section 3, $77-81 \mathrm{~cm}$

Core 2, Section 1, 43-46

Core 3, Section 3, 55-58
Core 40 , Section 2, 75-78

Core 43, Section 3, 97-100*

Core 44, Section 1, 95-98*

Core 45, Section 3, 68-71*

Core 46, Section 5, 101-104*

Core 47, Section 4, 103-105

Core 48, Section 2, 80-83*

Core 49 , Section 3, 85-88*

Core 50, Section 4, 105-108*

Core 51 , Section 3, 38-42*

Core 52, Section 3, 78-81*

Core 53, Section 1, 108-112*

Core 54, Section 2, 67-71*

Core 55, Section 2, 28-30*

Core 56, Section 2, 55-57*

Core 57, Section 2, $26-29 \mathrm{~cm} *$

Core 59, Section 1, 41-43*

Core 61 , Section 0 , core-catcher sample*

Core 9, Section 3, $57-61 \mathrm{~cm}^{*}$ Core 10, Section 3, 73-75* Core 11, Section 3, 46-49* Core 12, Section 3, 67-71* Core 13, Section 4, 85-88* Core 14 , Section 3, 58-62* Core 16, Section 2, 65-68* Core 17, Section 2, 71-74*

Core 3, Section 1, 66-68 cm Core 5, Section 2, 62-64

Core 3, Section 5, 101-107

Core 4, Section 2, 68-71 


\section{PLATE 1}

(Magnification $\times 500$, all figures photographed in normal transmitted light except where noted.)

Figures 1-4 Spiniferites mirabilis (Rossignol) Sarjeant, 1970. MPK 1626.

Sample 400A-1-1, 100-114 cm.

1. Dorsal view with archeopyle.

2. Optical section.

3. Optical section showing membranous antapical process.

4. Ventral view.

Figures 5-8 Leptodinium patulum Wall, 1967. MPK 1470.

Sample 400A-1-1, 100-114 cm.

5. Oblique dorsal view with archeopyle.

6. Oblique ventral view, MPK 1627. Sample 400A-12-3, 60-62 $\mathrm{cm}$.

7. Dorsal view with archeopyle.

8. Ventral view with sulcus and 1 in.

Figures 9,10 Tectatodinium pellitum Wall, 1967. MPK 1628.

Sample 400A-2-3, 63-67 cm.

9. Oblique dorsal view with archeophle.

10. Dorsal view showing archeopyle and thick wall layer, MPK 1629.

Figures 11-14, Amiculosphaera umbracula gen. et sp. nov. MPK 1630 22,23 Sample 400A-2-3, 63-67 cm.

11. Dorsal view with large periphragmal archeopyle.

12. Optical section showing flared apical process.

13. As above, phase contrast.

14. Ventral view, MPK 1631 .

22. Optical section showing small strudtures at the antapical/ post-cingular plate boundaries, MPK 1632.

23. Dorsal view with large periphragmal archeopyle.

Figure $15 \quad$ Leipokatium cf. invisitatum Bradford, 1975. MPK 1633.

Sample 400A-1-1, 100-114 cm. Lateral view.

Figure 16 Cyst of Protoperidinium subinerme (Paulsen) Loeblich, 1969 MPK 1634.

Sample 400A-7-2, 77-81 cm.

View of apical/antapically compressed specimen showing archeopyle and sulcus.

Figures 17,18 Leptodinium aculeatum Wall, 1967. MPK 1635.

Sample 400A-1-1, 110-114 cm.

17. Dorsal view with archeopyle.

18. Optical section with small apical boss and typical membranous sutures.

Figures 19,20 Leptodinium paradoxum Wall, 1967. MPK 1636.

Sample 400A-5-1, 70-74 cm.

19. Dorsal view with archeopyle.

20. Ventral view and sulcus.

Figure $21 \quad$ Nematosphaeropsis labyrinthea (Ostenfeld) Reid, 1974, MPK 1637.

Sample 400A-5-1, 70-74 cm.

Oblique dorsal view with archeopyle. 
PLATE 1
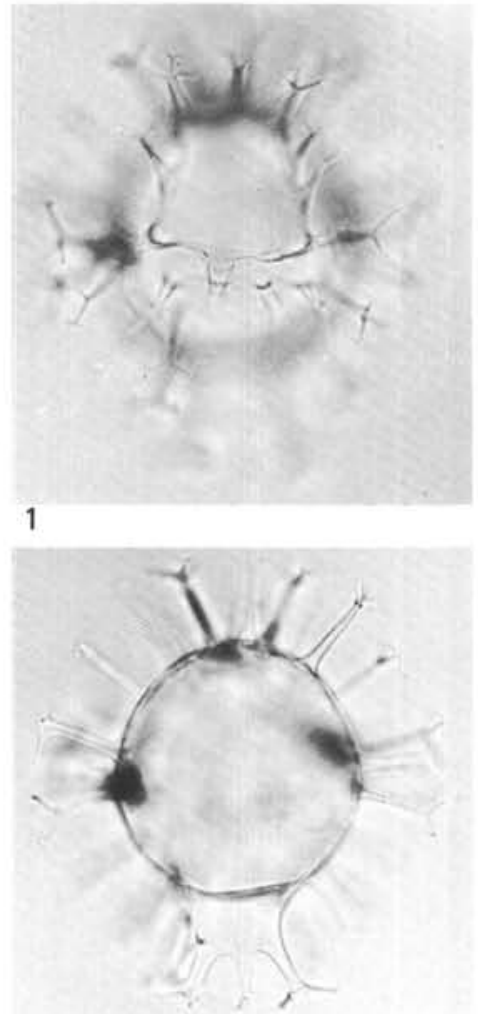

3

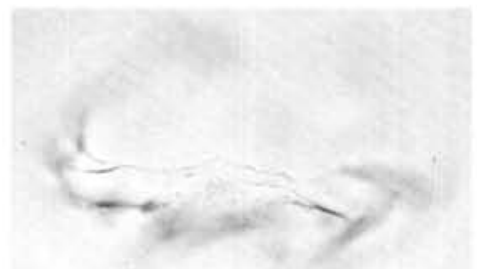

11

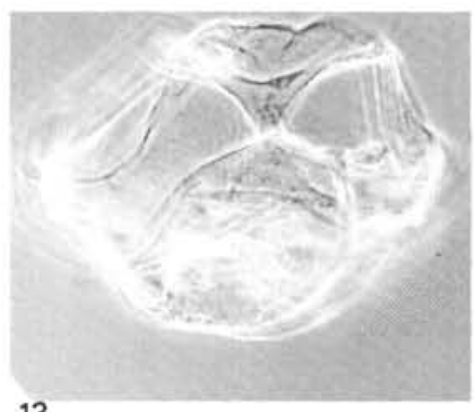

13

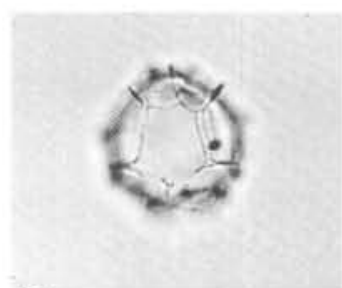

19
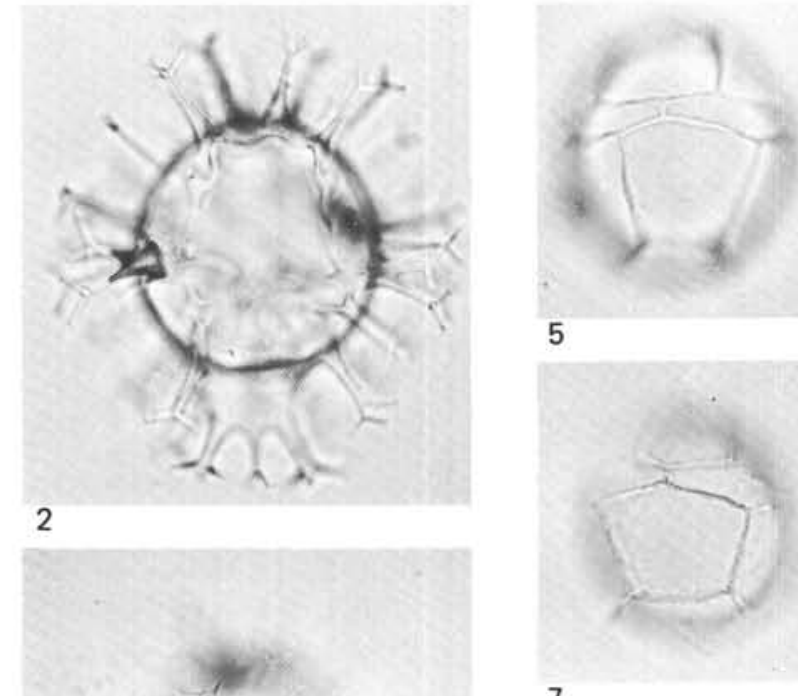

7

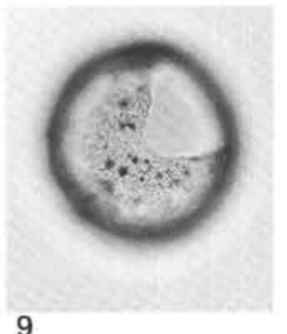

9

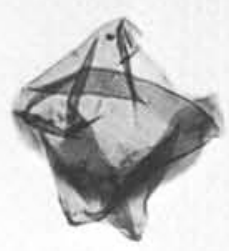

15

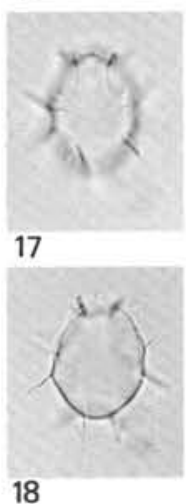

14
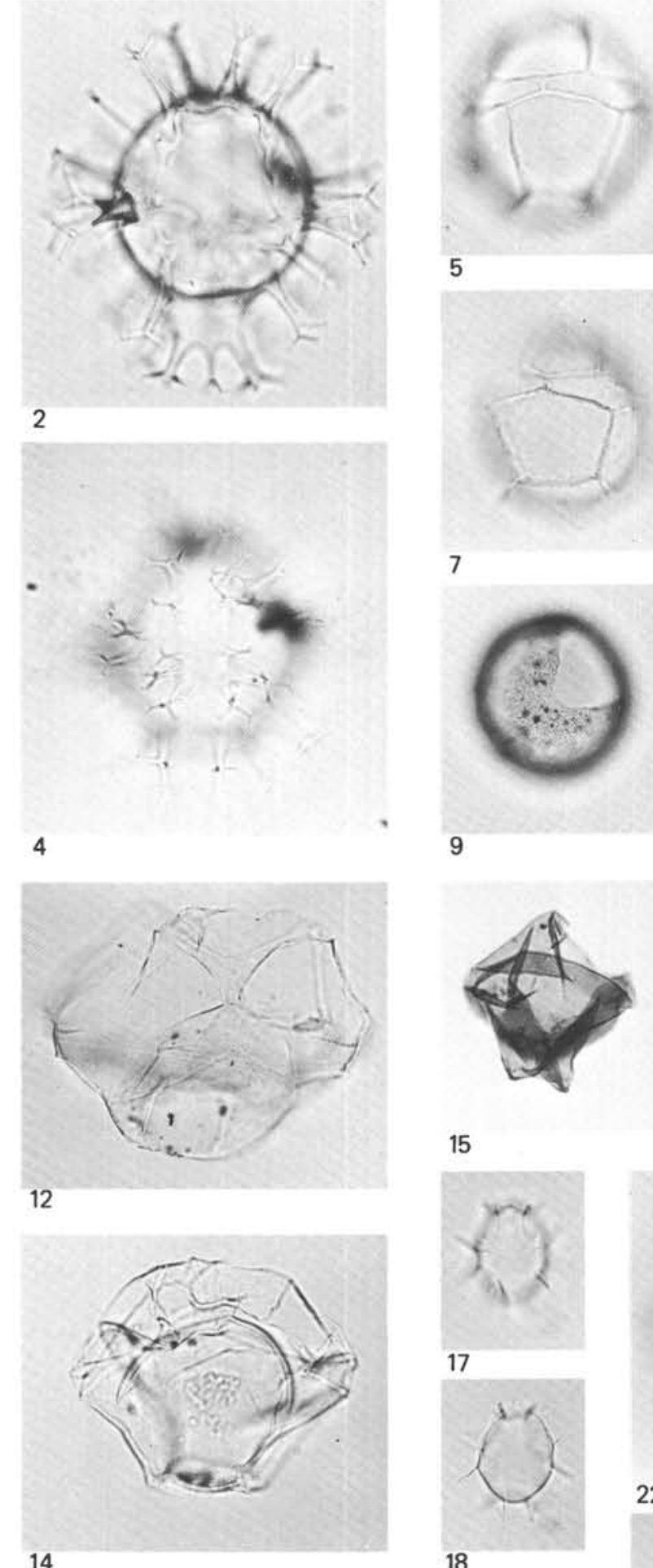

5
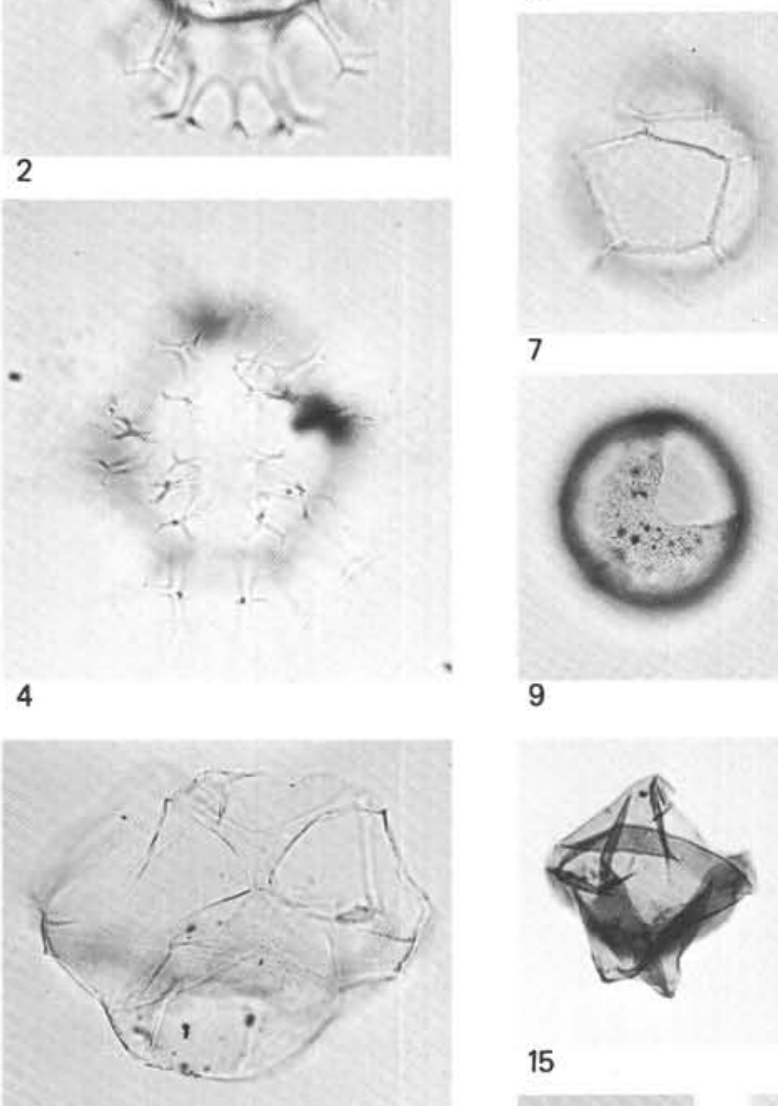

12
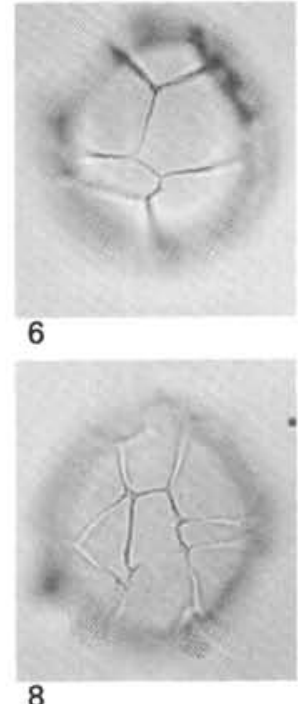

8

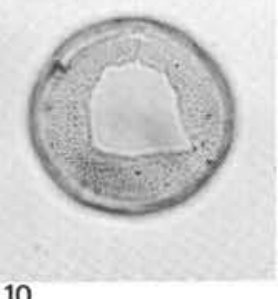

10

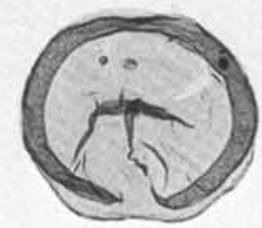

16

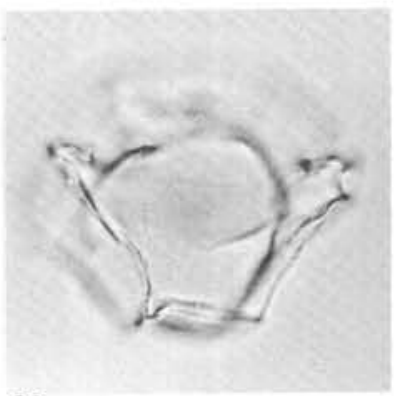

22

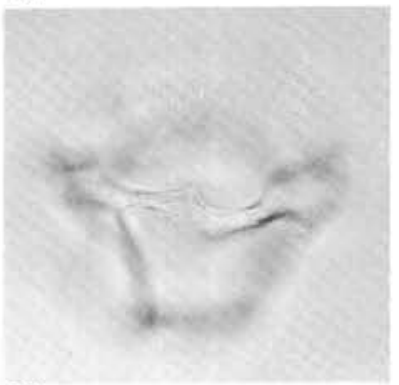

23 


\section{PLATE 2}

(Magnification $\times 500$, all figures photographed in normal transmitted light except where noted.)

Figures 1-3 Amiculosphaera umbracula gen. et sp. nov. Holotype. MPK 1638. Interference contrast.

Sample 400A-2-4, 100-102 cm.

1. Optical section with apical process and part of periphragmal archeopyle.

2. Ventral view with sulcus and two apical plates.

3. Dorsal view.

Figures 4-11 Spiniferites rubinus (Rossignol) Sarjeant, 1970. MPK 1639.

Sample 400A-2-5, 24-26 cm.

4. Oblique dorsal view with archeopyle and process development.

5. Oblique ventral view.

6. Dorsal view with archeopyle, MPK 1640.

7. Optical section, specimen with development of membranous processes.

8. Ventral view showing the apparently broad sulcus, MPK 1641. Sample 400A-2-5, 12-14 cm.

9. Dorsal view with archeopyle.

10. Optical section.

11. Ventral view.

Figures 12-14 Operculodinium crassum sp. nov. Holotype. MPK 1642.

Sample 400A-12-13, 60-62 cm.

12. Dorsal view with archeopyle.

13. Optical section showing thick wall.

14. Ventral view.

Figure 15 "Thalassiphora delicata" Williams and Downie emend. Eaton, 1976. MPK 1643. Phase contrast. Sample 400A-7-3, 62-64 cm.

Oblique dorsal view.

Figure 16 Hystrichokolpoma cf. poculum Maier, 1958. MPK 1644.

Sample 400A-5-1, 70-74 cm.

Dorsal view showing nature of processes and lack of cingular processes.

Figures 17, 18 ?Ellipsodinium sp. MPK 1645.

Sample 400A-8-3, 62-64 cm.

17. Dorsal view with ?pre-cingular archeopyle.

18. Ventral view.

Figures 19,20 Spiniferites cf. pseudofurcatus (Klumpp) Sarjeant, 1970. MPK 1646.

Sample 400A-8-3, 62-64 cm.

19. Oblique dorsal view with archeopyle.

20. Oblique ventral view with process morphology. 
PLATE 2
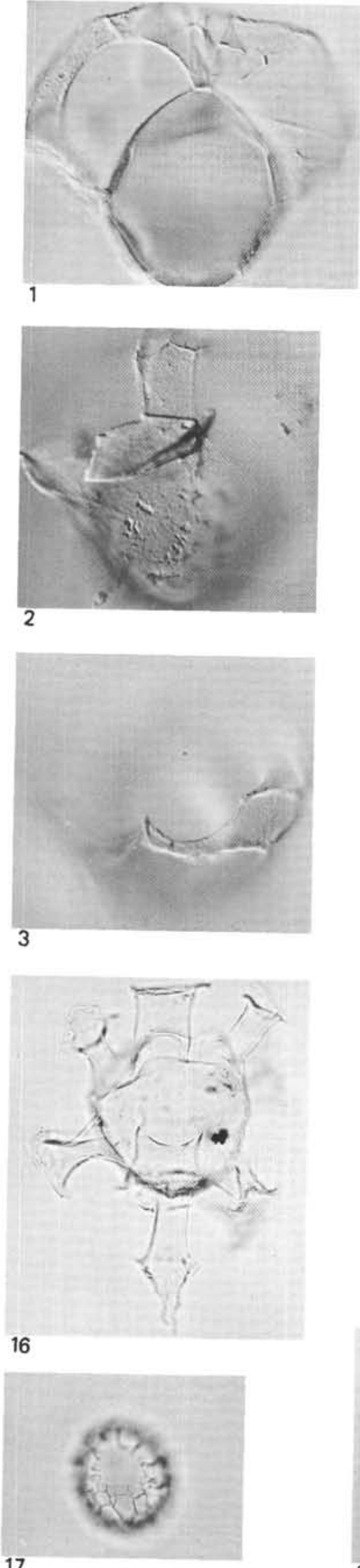
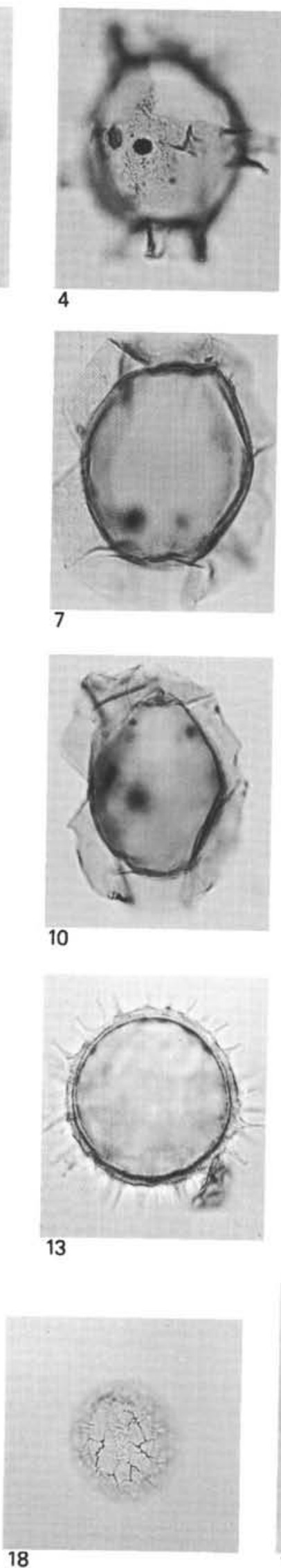

18
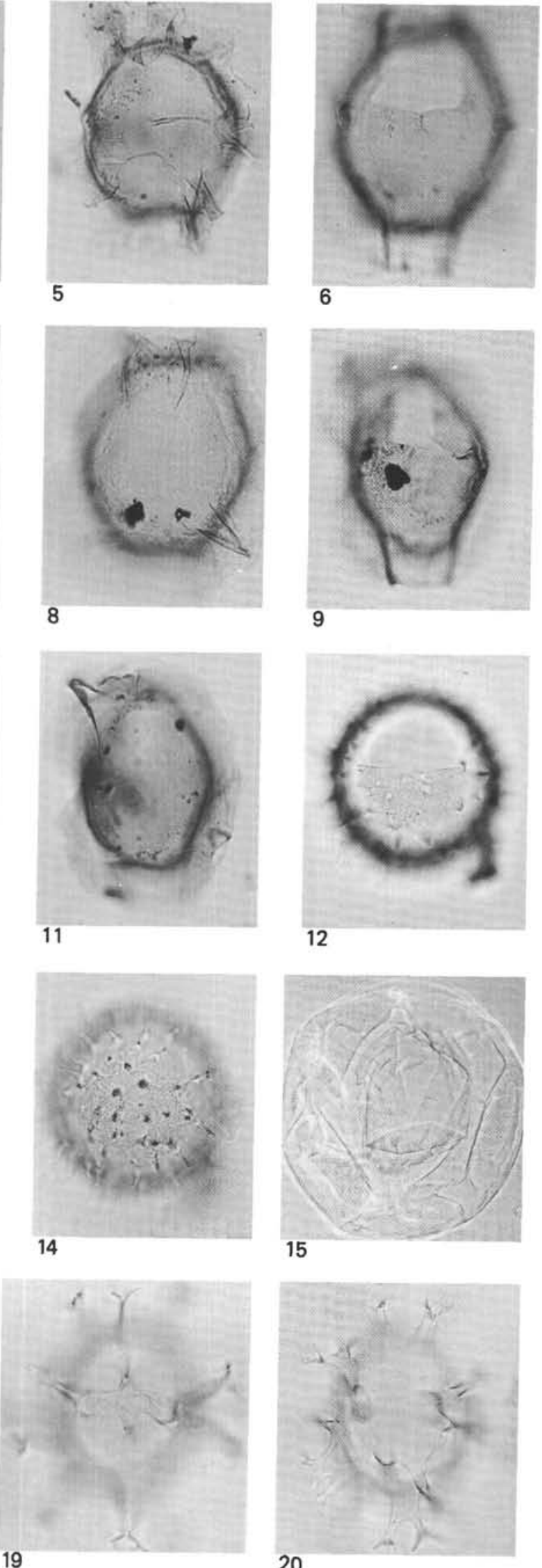
PLATE 3

(Magnification $\times 500$, all figures photographed in normal transmitted light.)

Figures 1,2 Spiniferites splendidus sp. nov. Holotype. MPK 1647. Sample 400A-15-3, 67-71 cm.

1. Oblique dorsal view with archeopyle and process morphology. MPK 1648. Sample 400A-14-2, 63-67 cm.

2. Oblique dorsal view with complex membranous antapical process.

Figures 3,4 Pentadinium taeniagerum Gerlach, 1961. MPK 1649 Sample 400A-30-1, 22-25 cm.

3. Dorsal view with archeopyle.

4. Ventral view.

Figures 5-7 "Hystrichosphaeridium" cf. choanophorum Deflandre and Cookson, 1955. MPK 1650.

Sample 400A-14-2, 63-67 cm.

5. Orientation unknown, overall morphology. MPK 1651. Sample 400A-20-3, 70-73 cm.

6. Orientation unknown, showing nature of processes.

7. Orientation unknown, possible archeopyle.

Figure $8 \quad$ Tuberculodinium sp. MPK 1652.

Sample 400A-15-3, 67-71 cm.

Apical view showing overall morphology.

Figure $9 \quad$ Wetzeliella sp. MPK 1653.

Sample 400A-20-3, 70-73 cm.

Dorsal view with archeopyle.

Figures 10,11 ?Pyxidiella cf. scrobiculata (Deflandre and Cookson) Cookson and Eisenack, 1958. MPK 1654. Sample 400A-25-7, 8-11 cm.

10. Oblique dorsal view with intercalary archeopyle.

11. Oblique ventral view showing ornamentation.

Figures 12-15 ?Pyxidiella simplex sp. nov. Holotype. MPK 1655. Sample 400A-24-6, 88-91 cm.

12. Dorsal view with intercalary archeoplye and ovoidal pentagonal outline.

14. Lateral view with conate ornament, MPK 1656.

15. Optical section showing the ornament of cones. MPK 1657. Sample 400A-15-3, 67-71 cm.

13. Dorsal view with intercalary archeopyle and ovoidal outline.

Figure 16 Operculodinium sp. MPK 1658. Sample 400A-14-2, 63-67 cm.

Dorsal view with archeopyle showing ornamentation.

Figure 17 Cannosphaeropsis sp. MPK 1659.

Sample 400A-24-6, 88-91 cm.

Lateral view with archeopyle. 
PLATE 3

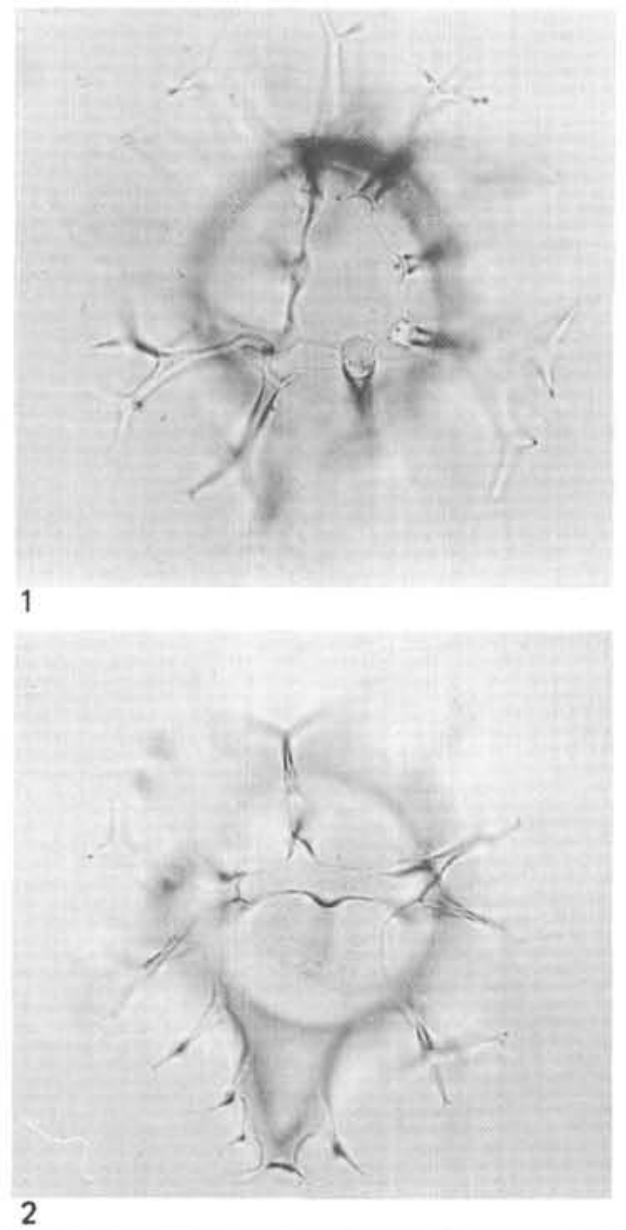

3
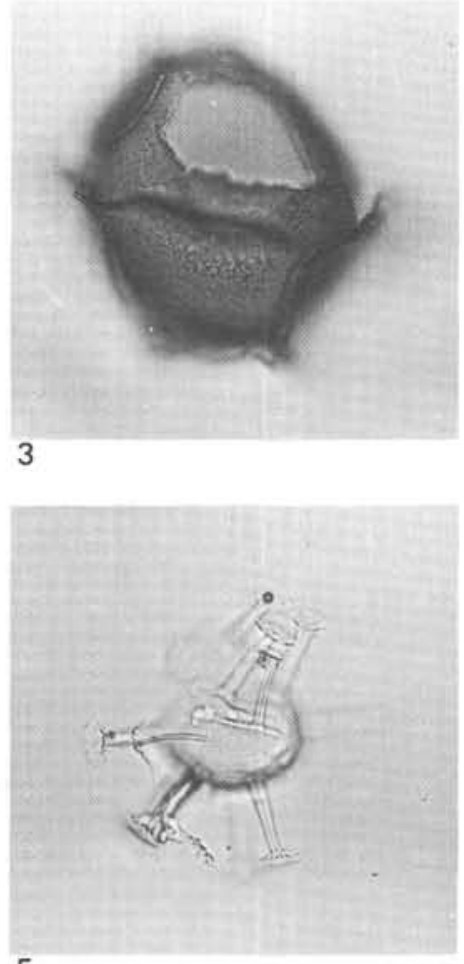

5

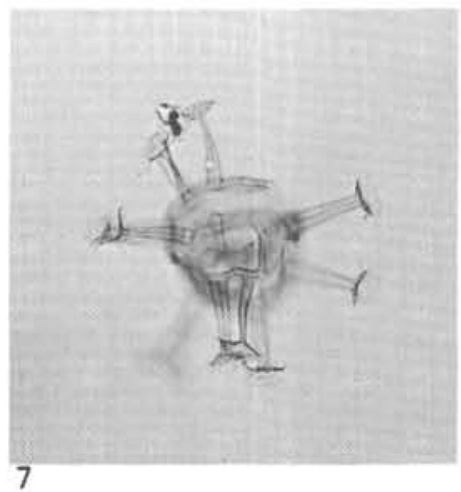

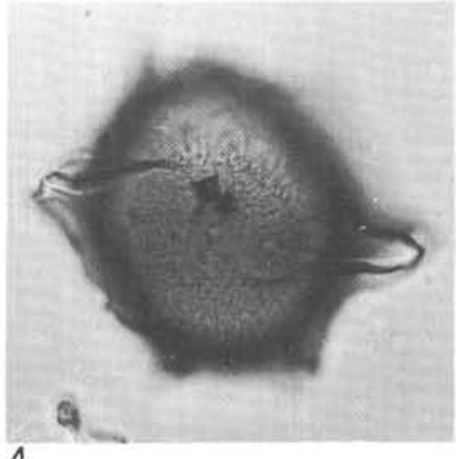

4
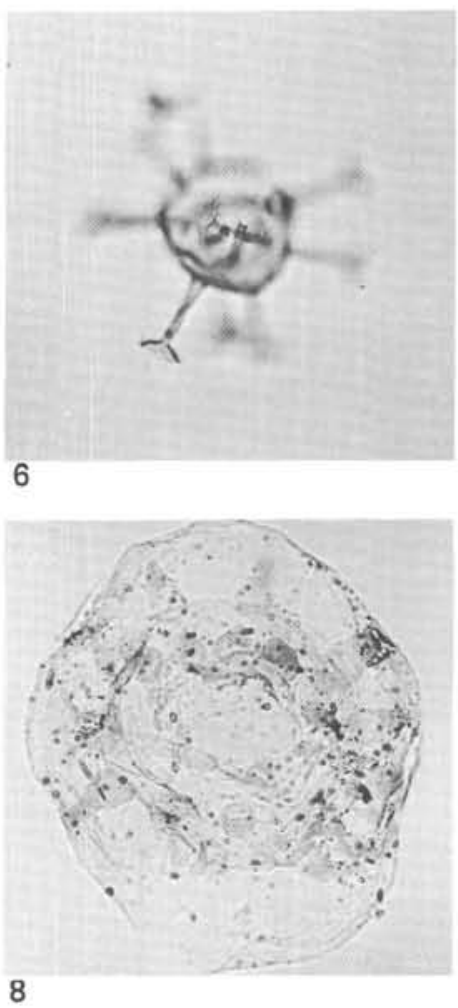

8
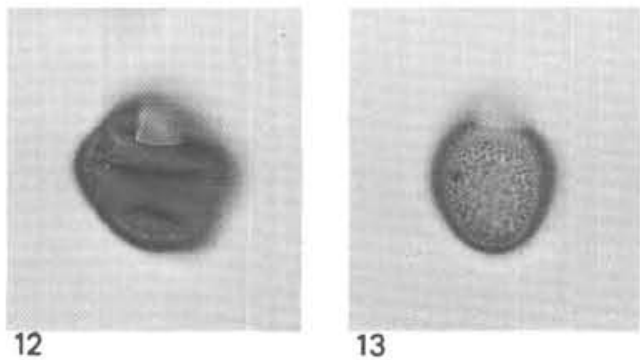

13
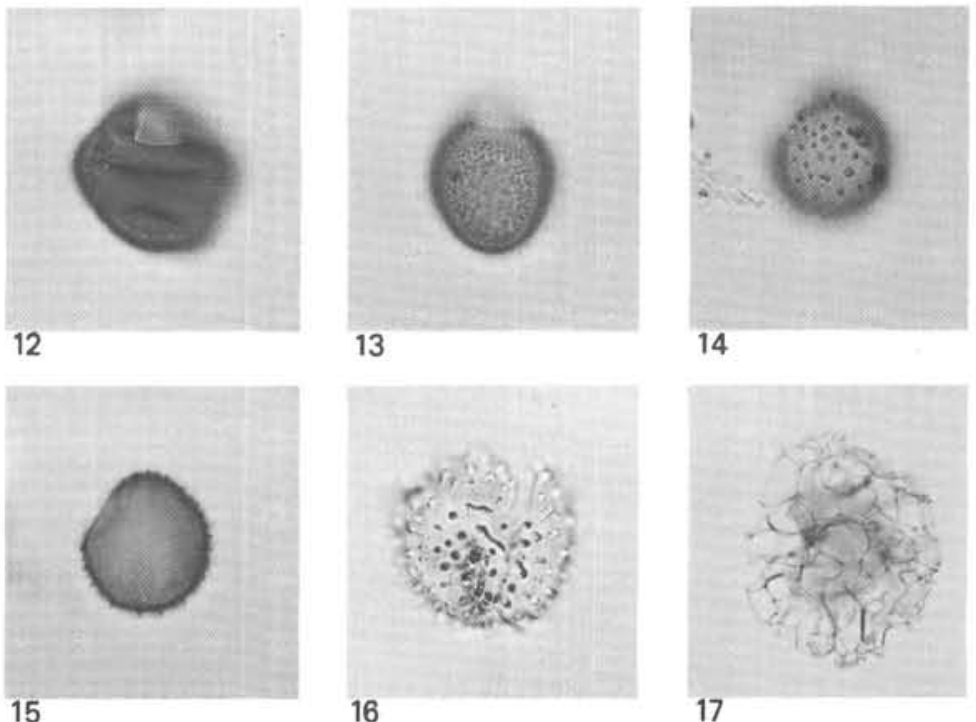

14

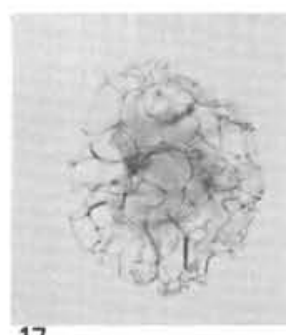

15

16

17

10

11 